Jurnal Interpretasi Hukum | ISSN: 2746-5047

Vol. 2, No. 3-Desember 2021, Hal. 667-672| Tersedia online di

https://www.ejournal.warmadewa.ac.id/index.php/juinhum

DOI: https://doi.org/10.22225/juinhum.2.3.4175.667-672

\title{
EKSPLOITASI ANAK SEBAGAI PEDAGANG ASONGAN DITINJAU DARI UU PERLINDUNGAN ANAK PADA MASA PANDEMI COVID-19
}

\author{
I Ketut Wira Cipta Putra, Anak Agung Sagung Laksmi Dewi, Ni Made Sukaryati Karma, \\ Fakultas Hukum, Universitas Warmadewa, Denpasar-Bali,Indonesia \\ putrawiracipta@gmail.com, laksmidewi29@gmail.com, madesukaryatikarma@gmail.com
}

\begin{abstract}
Abstrak
Pengaturan hukum tindak eksploitasi anak selama pandemi Covid-19 belum termuat dalam Kitab Undangundang Hukum Pidana (KUHP). Sehingga orang tua yang mempekerjakan anaknya sebagai pedagang asongan masih bebas dari jerat hukum dan dengan mudah melakukan pembenaran secara ekonomi. Penelitian ini bertujuan untuk menelaah pengaturan hukum terhadap pelaku tindak pidana eksploitasi anak sebagai pedagang asongan dan mengungkapkan sanksi pidana bagi pelaku tindak eksploitasi terhadap anak sebagai pedag ang asongan pada masa Pandemi Covid-19. Metode penelitian ini menggunakan penelitian hukum normative dengan menerapkan pendekatan konseptual dan Perundang-undangan. Data yang digunakan yaitu data hukum primer, sekunder dan tersier yang diperoleh dengan metode pencatatan. Setelah data terkumpul, tahap selanjutnya diolah dan dianalisis secara interprensi hukum yang secara sistematis. Hasil Penelitian menunjukkan pengaturan hukum terhadap pelaku tindak pidana eksploitasi terhadap anak pada masa pandemi Covid-19 salah satunya eksploitasi anak tidak diatur secara khusus pada Pasal 13 Undang-undang No. 35 Tahun 2014 perubahan atas Undang-undang No. 23 Tahun 2002 tentang Perlindungan Anak. Oleh karenanya dalam hal ini terjadi kekosongan norma, akan tetapi tindak pidana eksploitasi anak berdasarkan ketentuan Pasal 103 dalam KUHP menyatakan jika kejahatan terhadap anak merupakan suatu pidana khusus. Terkait sanksi tindak pidana yaitu dipidana dengan pidana penjara paling lama sepuluh tahun atau denda paling banyak Rp. 200.000.000,00 (dua ratus juta rupiah).
\end{abstract}

Kata Kunci: Eksploitasi Anak, Pengaturan Hukum, Pedagang Asongan

\begin{abstract}
Legal arrangements for child exploitation during the Covid-19 pandemic have not yet been included in the Criminal Code (KUHP). So that parents who employ their children as hawkers are still free from legal snares and can easily justify economically. This study aims to examine the legal arrangements for perpetrators of criminal acts of child exploitation as hawkers and reveal criminal sanctions for perpetrators of acts of exploitation of children as hawkers during the Covid-19 pandemic. This research method uses normative legal research by applying a conceptual approach and legislation. The data used are primary, secondary and tertiary legal data obtained by the recording method. After the data has been collected, the next step is to process and analyze it in a systematic way with legal intervention. The results of the study show that legal arrangements for perpetrators of criminal acts of exploitation of children during the Covid-19 pandemic, one of which is child exploitation, are not specifically regulated in Article 13 of Law no. 35 of 2014 amendments to Law no. 23 of 2002 concerning Child Protection. Therefore, in this case there is a void of norms, but the crime of child exploitation based on the provisions of Article 103 of the Criminal Code states that crimes against children are a special crime. Related to criminal sanctions, they are sentenced to a maximum imprisonment of ten years or a maximum fine of Rp. 200,000,000.00 ( $t$ wo hundred million rupiah).
\end{abstract}

Keywords: Child Exploitation, Legal Arrangements, Peddlers

\section{PENDAHULUAN}

Tindakan eksploitasi terhadap anak merupakan tindakan yang melanggar Undang-undang, karena Tindakan eksploitasi akan menghilangkan sebagian bahkan sepenuhnya hak-hak anak (Piri, 2013). Oleh karena itu, pemerintah melakukan upaya untuk melindungi anak-anak dari kasus eksploitasi tersebut dengan menetapkan UU perlindungan anak dan sanksi terhadap pelaku eksploitasi anak. UU N0.23 Tahun 2002 tentang Perlindungan Anak, sebagaimana telah diubah menjadi UU No.35 Tahun 2014 adalah ketetapan yang membahas dan menjamin hak-hak anak yang harus mereka dapatkan, serta memberikan perlindungan hukum terhadap anak-anak jika mereka mendapatkan perlakuan yang tidak sesuai dengan peraturan tersebut (Marlienna, 2017). 
Kasus eksploitasi terhadap anak-anak, harus mendapat perhatian serius oleh berbagai pihak, khususnya pemerintah. Seperti pada contoh kasus dari KPAI terjadi penculikan anak yang masih di bawah umur dijalankan oleh seseorang yang tanpa dikenali ataupun dari oerang yang paling dekat dengan korban dalam eksploitasi yang secara ekonomi ataupun sesksual, dimana kasus ini merupakan tetangga korban yang menjadi pelaku dalam sebuah tindakan eksploitasi anak. Terkait tindak eksploitasi anak secara ekonomi yang seringkali dilakukan oleh orang tuanya ataupun oleh pihak yang lain, terkadang lolos dari jerat hukum (Atmasasmita, 1997). Hal ini karena berbagai macam alasan seperti pembenaran akibat kondisi ekonomi yang sangat memprihatinkan, padahal belum tentu orang tua tidak bisa mencari pekerjaan sehingga harus mengorbankan anak-anak mereka. Sehingga, aparat yang menegakkan hukum sudah waktunya untuk memberikan hukuman yang dapat menjadikan efek jera bagi pelaku eksploitasi anak (Raharjo, 2002).

Sanksi pelaku eksploitasi sendiri tersebut nampaknya belum dimuat pada KUHP sehingga orang tua yang mempekerjakan anaknya sebagai pedagang asongan masih bebas dari jerat hukum dan seenaknya melakukan pembenaran secara ekonomi. Pada UU No.39/1999 mengenai HAM Bagian Kesatu Pasal 9. Dengan berdasarkan atas Pasal tersebut, maka orangtua yang mempekerjakan anaknya sebagai pedagang asongan dapat berdalih dengan alasan mempertahankan hidup, sehingga hal ini bertentangan dengan UU No.35/2014 Pasal 76 I tentang Perlindungan terhadap anak dari eksploitasi secara ekonomi dan seksual. Selain itu, jika hukuman bagi orang tua yang mempekerjakan anaknya sebagai pedagang asongan mendapat jerat hukum secara pidana baik kurungan maupun denda, maka akibat yang muncul akan menjadi lebih kompleks, salah satunya adalah anak-anak mereka yang terancam terlantar. Hal ini tentunya menimbulkan konflik, karena orang tua dianggap menelantarkan anaknya yang dimuat pada UU No.35/2014 Pasal76B.

Penelantaran ini akan menimbulkan konflik bagi anak, dan juga bagi negara ketika tidak mampu menggantikan peran sebagai orang tua untuk merawat serta memelihara anaknya (Piri, 2013). Seorang anak menjadi harapan dalam meneruskan bangsa, diperlukan memperoleh sebuah perhatian yang secara maksimum baik dari pemerintahan ataupun melalui masyarakat. Untuk menjadi harapan bangsa setidaknya kesejahtraan yang harus dimiliki dari seorang anak serta memperoleh sebuah perhatian yang besar supaya seorang anak mampu berkembang menjadi penerus bangsa yang mampunyai kualitas tinggi (Anggraini, 2020). Namun, harapan tersebut tidak berjalan dengan baik, karena masih banyaknya anak-anak yang harus ikut bekerja sebagai upaya dalam pemenuhan kebutuhan ekonomi keluarganya. Salah satunya adalah menjadi pedagang asongan. Dikutip dari laman resmi pemerintah Kota Denpasar, pedagang asongan atau Pedagang Kaki Lima (PKL) yang melibatkan anak-anak kian bermunculan.

Komisi Perlindungan Anak Indonesia (dalam kpai.go.id) menyebutkan bahwa pada tahun 2020, permasalahan mengenai pekerjaan anak makin berkompleks karena adanya wabah dari pandemik Covid-19 sehingga memberikan dampak yang cukup signifikan kepada prekonomian serta sosial (Pramandari \& Parwita, 2013). Namun pada situasi ini justru ada sebagian keluarga yang memanfaatkannya untuk menjadikan anak sebagai tulang punggung dalam memberikan penambahan pada penghasilan keluarganya. Salah satunya adalah menjadi pedagang asongan .

Perda No.1/2015 tentang permasalahan secara mendasar terjadi di Kota Denpasar telah mengatur bahwa pedangang asongan atau PKL tidak diperbolehkan beroperasi karena mengganggu ketertiban umum. Pelanggaran ini tentu tidak bisa dilanjutkan ke Sidang Tipiring karena mereka yang masih dibawah umur atau anak-anak, karena mereka dilindungi oleh Undang-undang Perlindungan Anak. Namun, pihak anak-anak tidak diperhatikan karena orang tua mereka berdalih dengan menyatakan bahwa berjualan juga bagian dari membiayai sekolah. Padahal Tindakan tersebut dapat tergolong eksploitasi terhadap anak. Sebagaimana disebutkan dalam Pasal59 (2d) UU No.34/2014.

Kondisi pandemi Covid-19 telah memberikan tekanan ekonomi yang cukup besar kepada seluruh lapisan masyarakat. Pelemahan ekonomi menyebabkan kebutuhan hidup susah untuk dipenuhi, hal ini mampu memberi sebuah dampak yang signifikan kepada anak-anak, karena orang tua mereka sebagian besar mengalami kesulitan kerja, sehingga mendorong anak-anak menjadi korban ekspoitasi sebagai pedagang. Sebelum adanya pandemi pun kondisi anak-anak yang menjadi pedagang asongan sudah memprihatinkan, terlebih ketika terjadi pandemi Covid-19, tentunya akan menjadi lebih sulit bagi mereka. Ketiadaan dari aturan khusus yang mengatur terkait pedagang asongan yang dilakukan oleh anak-anak, menyebabkan adanya peluang bagi oknum tertentu 
khususnya orang tua yang tidak bertanggungjawab untuk melakukan eksploitasi terhadap anak dengan kedok ekonomi. Hal ini tentunya akan merenggut masa anak-anak mereka dengan segala hak yang seharusnya mereka dapatkan (Manggala et al., 2021). Adanya eksploitasi ekonomi terhadap anak dengan menyuruh mereka menjadi pedagang asongan, tentunya sudah mengurangi hak yang seharusnya mereka dapatkan salah satunya hak untuk bermain dan belajar, karena waktu mereka habis digunakan untuk berjualan di jalanan (Subhan, 2018).

Berdasarkan hasil survey Kementerian Pemberdayaan Perempuan, dapat diketahui bahwa hamper sebagian besar anak-anak membantu pekerjaan orang tua, dan masih ada anak-anak yang dipaksa membantu orang tua mereka. Alasan ini tentunya menjadi konflik bagi anak itu sendiri. Ingin dan rela ataupun dipaksa untuk bekerja tentunya memberikan dampak negatif bagi tumbuh kembang anak. Hal ini karena hak-hak mereka yang harusnya mereka dapatkan tidak bisa mereka nikmati (Fitriani, 2016). Upaya perlindungan bagi anak yang dieksploitasi saat ini oleh pemerintah masih belum mampu memberikan pengaruh maksimal, begitu pula dengan aparat penegak hukum, masyarakat, dan pihak-pihak terkait lainnya yang berhak membantu. Melalui penjatuhan sanksi hukum seharusnya mampu memberikan keadilan, namun sebaliknya eksploitasi yang dilakukan oleh orangtua kepada anaknya secara ekonomi masih mendapat pembenaran dengan berbagai alasan. Inilah bentuk ketidakadilan hukum yang dianggap dapat mengakibatkan jatuhnya masyarakat yang lemah (menjadi korban suatu kejahatan) agar diharuskan berurusan dalam dunia peradilan (Edy et al., 2020).

Berdasarkan fenomena di atas, maka penelitian ini dilakukan dengan tujuan untuk menelaah pengaturan hukum terhadap pelaku tindak pidana eksploitasi anak dan mengungkapkan sanksi pidana bagi pelaku tindak eksploitasi terhadap anak pada masa pandemi covid-19.

\section{METODE PENELITIAN}

Tipe penelitian ini menggunakan penelitian hukum normatif. Peneliti melakukan kajian pada peraturan hukum yang memakai literatur menjadi konsep, teori serta pendapat dari ahli hukum pada permasalahan yang selanjutnya akan dianalisis. Pendekatan peneltian ini menggunakan pendekatan konseptual dan Perundang-undangan. Pada metode yang menggunakan pendekatan Perundangundangan peneliti butuh untuk paham dengan hierarki dan asas-asas pada aturan Perundang-undangan (Asikin \& Amiruddin, 2012). Sumber bahan hukum menggunakan bahan hukum tersier, sekunder, dan primer. Pengumpulan bahan hukum memakai teknik pencatatan. Bahan hukum yang terkumpul selanjutnya diolah dan dianalisis untuk memperoleh suatu kebenaran dan berusaha untuk memahami kebenaran tersebut. Bahan hukum yang sudah terkumpul dan telah dikelompokan serta dianalisis serta diolah memakai metode interprensi hukum yang secara sistematis, diberikan penafsiran dengan argumentasi untuk mendapatkan suatu simpulan yang bersifat tepat, benar, dan ilmiah, serta logis sebagai hasil akhir penelitian ini.

\section{HASIL DAN PEMBAHASAN}

\section{Pengaturan Hukum Terhadap Pelaku Tindak Pidana Eksploitasi Terhadap Anak}

Seorang anak kecil yang diberdayakan untuk berdagang asongan di pinggir jalan agar menarik simpati masyarakat membeli barang dagangannya, untuk memperoleh sebuah uang yang tidak sedikit tanpa melihat kehidupan serta pendidikan masa kecilnya. Terlebih pada masa Pandemi Covid-19, tindakan eksploitasi anak secara ekonomi lebih marak terjadi. Hal tersebut dikarenakan banyak orang tua ataupun oknum yang mengalami kesulitan ekonomi dan mengambil jalan yang tidak benar dengan memanfaatkan anak untuk berdagang atau berjualan.

Anak merupakan tunas muda bangsa. Oleh karenanya perlindungan terhadap anak mendapat perhatian serius dari Negara (Nashriana, 2011). Hal tersebut tercantum dalam ketentuan pasal-pasal dalam UU Perlindungan anak. Pada masa Pandemi Covid-19, di Kota Denpasar banyak ditemui pedagang asongan yang dijalankan oleh seorang anak yang masih berada di bawah umur. Memanfaatkan anak untuk berdagang asongan termasuk bentuk eksploitasi secara ekonomi. Seseorang anak yang diekploitasi secara ekonomi dalam bentuk berdagang asongan tergolong sebagai korban, karena anak tersebut mengalami kerugian secara ekonomi.

Pengaturan hukum eksploitasi terhadap anak khususnya eksploitasi secara ekonomi pada masa pandemi covid 19, dalam bentuk pemanfaatan anak untuk berdagang asongan diatur pada Pasal 13 (1b) UU perlindungan anak, menjelaskan bahwa seorang anak memiliki hak untuk memperoleh rasa 
aman dari tindakan eksploitasi baik secara seksual ataupun ekonomi. Diperkuat dengan ayat (2) yang menjelaskan bahwa, akan diberikan pemberatan hukuman apabila pihak yang melakukan eksploitasi tersebut adalah pengasuh dari seorang anak, wali, serta orang tuanya.

Dengan demikian, tindakan setiap orang, baik itu orang tua atau orang lain yang memberikan pekerjaan kepada seorang anak untuk menjadi pedagang asongan termasuk sebagai sebuah kegiatan dari eksploitasi kepada anak dari segi ekonomi. Selain pasal 13, perlindungan anak terhadap kejahatan eksploitasi juga dipertegas dalam pasal 59 (1) serta (2), Selanjutnya dalam pasal 66 yang menjelaskan mengenai upaya-upaya apa saja yang harus dijalankan oleh pemerintahan Daerah, lembaga pemerintahan, serta lembaga lain yang pada hal mampu memberikan sebuah perlindungan khusus terhadap anak yang menjadi korban eksploitasi ekonomi.

Ketentuan Pasal 13 (1) UU Perlindungan Anak telah mencerminkan implementasi asas negara hukum yang sangat perduli terhadap kesejahteraan bangsa terutama kesejahteraan terhadap seorang anak yang berada pada masa pandemic covid-19. Seorang anak merupakan ujung tombak bangsa Indonesia sehingga harus dilindungi dengan baik agar bisa bertumbuh dan berkembang dengan cara sejahtera lahir dan batin. Akan tetapi, dalam peraturan Perundang-undang Indonesia belum memberikan peraturan yang secara khusus terkait ketindak pidanaan dari ekploitasi kepada seorang anak yang terjadi pada masa Pandemi Covid-19. Peraturan yang digunakan baik terkait dengan larangan dan sanksi terhadap pelaku, masih menggunakan UU Perlindungan anak. Dimana dalam penjabaran tindak pidana eksploitasi ekonomi kepada seorang anak tidak secara spesifik menjelaskan eksploitasi ekonomi yang terjadi akibat Pandemi Covid-19. Oleh karenanya dalam hal ini terjadi kekosongan norma terhadap pengaturan hukum tindak pidana eksploitasi ekonomi anak yang terjadi dalam masa Pandemi Covid-19. Dengan demikian, maka sudah sangat jelas bahwa melakukan eksploitasi terhadap anak secara ekonomi termasuk salah satunya adalah eksploitasi anak sebagi pedagang asongan merupakan suatu tindak kejahatan yang serius dan diancam dengan pidana yang cukup berat.

\section{Sanksi Pidana Bagi Pelaku Tindak Eksploitasi Terhadap Anak pada Masa Pandemi Covid-19}

Sanksi pidana merupakan akibat dari suatu perbuatan atau tindak pidana. Akibat dari suatu perbuatan yang tergolong pelanggaran akan melahirkan sebuah sanksi (Hutahaean, 2013). Terkait hukuman moril umumnya terjadi atau sumbernya dari masyarakat sekitar atau pun dari instansi tempat seseorang bekerja, sedangkan berkaitan dengan hukuman atau sanksi fisik umumnya diberikan oleh pihak yang memiliki wewenang. Sanksi merupakan suatu kosakata yang sering digunakan dalam setiap aturan atau proses hukum di kalangan masyarakat. Salah satu aturan yang menggunakan istilah sanksi di dalamnya yaitu KUHP. Sanksi Pidana merupakan akibat dari sebuah perbuatan pidana. Perbuatan pidana mampu terbagi menjadi dua yakni pidana yang memiliki sifat khusus serta pidana yang memiliki sifat umum. Adapun perbuatan pidana yang melanggar Undang-undang Perlindungan Anak termasuk ke dalam Pidana Khusus.

Berdasarkan ketentuan Pasal 103 dalam KUHP menyatakan jika kejahatan terhadap Anak merupakan suatu pidana khusus, yang mana sanksi pidananya juga khusus diatur dalam UU No.23/2003 Tentang Perlindungan Anak serta UU No.35/2014. Berdasarkan hal tersebut diketahui bahwa perbuatan pidana terhadap seseorang yang tergolong anak-anak masuk ke sebuah tindak pidana yang memiliki sifat khusus. Karena termasuk ke dalam tindak pidana khusus, maka sanksi yang menjeratnya juga merupakan sanksi pidana khusus. Suatu tindak pidana khusus akan diatur dalam UU yang secara spesifik hanya mengatur mengenai tindak kepidanaan tersebut. Terkait dengan tindak pidana terhadap anak terdapat peraturan perundang-undangan yaitu UU Perlindungan Anak.

Sanksi diberikan terhadap seorang individu yang apabila melakukan suatu perbuatan salah yang benar-benar berlebihan. Penjatuhan sanksi terhadap pedagang asongan yang berjualan tidak pada tempatnya umumnya diatur dalam peraturan daerah. Hal tersebut bergantung pada ketentuan tata ruang masing-masing daerah. Khususnya pada Kota Denpasar termuat aturan daerah No.1/2015 mengenai ketertiban umum yang memuat mengenai wilayah atau daerah mana saja yang memperbolehkan seseorang berdagang asongan. Pedagang asongan pada kenyataannya banyak dilakoni oleh anak-anak. Sesungguhnya memberdayakan seorang anak untuk berdagang asongan merupakan suatu yang bertentangan dengan undang-undang. Seorang anak apabila dipekerjakan sebagai pedagang asongan termasuk suatu tindakan eksploitasi terhadap anak. 
Suatu tindakan eksploitasi anak untuk berdagang asongan dikatakan pebagai eksploitasi secara ekonomi karena memberi keuntungan materi terhadap suatu pihak. Seseorang yang mempekerjakan anak tersebut untuk berdagang asongan akan memperoleh keuntungan secara ekonomi yang didapat dari hasil penjualan asongan anak tersebut. Oleh karenanya maka seorang anak yang dieksploitasi secara ekonomi melalui berdagang asongan merupakan suatu tindak pidana.

Adapun sanksi yang diberikan kepada seorang yang melakukan eksploitasi ekonomi melalui berdagang asongan kepada seorang anak telah diatur pada UU perlindungan anak kepada eksploitasi baik ekonomi maupun seksual. Penjatuhan sanksi tidak hanya diberikan kepada seseorang yang melakukan eksploitasi baik ekonomi maupun seksual, tetapi diberikan juga kepada orang yang melakukan pembiaran terhadap tindakan tersebut. Adapun sanksinya diatur dalam Pasal 78 UU No.23/2002 tentang Perlindungan anak.

Sanksi kepada seorang pelaku yang melakukan tindak pidana eksploitasi anak secara ekonomi dalam bentuk pedagang asongan bukan hanya termuat didalam UU. Peraturan Daerah Kota Denpasar mengatur mengenai sanksi terhadap pedagang asongan yang berjualan tidak pada lokasi yang disediakan. Karena anak-anak korban eksploitasi berdagang asongan sembarang tempat, misalnya persimpangan jalan. Adapun sanksi yang dikenkan sesuai dengan aturan daerah yang ada di Denpasar No.1/2015 mengenai ketertiban umum. Dampak dari penjatuhan sanksi bertujuan untuk meminimalisir orang tua/wali atau pihak lain melakukan eksploitasi terhadap anak. Sehingga diberikan sanksi pidana berupa kurungan atau denda yang mana tujuannya agar menghasilkan efek jera. Akan tetapi selain memberikan sanksi terhadap pelaku eksploitasi anak, perlindungan terhadap anak korban eksploitasi juga perlu diberikan.

\section{SIMPULAN DAN SARAN}

\section{Simpulan}

Berdasarkan hasil analisis data dapat disimpulkan bahwa pengaturan hukum terhadap pelaku tindak pidana eksploitasi terhadap anak secara ekonomi pada masa Pandemi Covid-19 tidak diatur secara khusus dalam Undang-undang. Oleh karenanya dalam hal ini terjadi kekosongan norma. Akan tetapi tindak pidana eksploitasi anak secara ekonomi apabila ditinjau dari peraturan undang-undang bersifat khusus baik jenis tindak pidananya, penyelesaiannya, dan sanksinya. Berdasarkan ketentuan Pasal 103 dalam KUHP menyatakan jika kejahatan terhadap Anak merupakan suatu pidana khusus, yang mana sanksi pidananya juga khusus diatur dalam UU Nomor 23 Tahun 2003 tentang Perlindungan Anak dan UU Nomor 35 Tahun 2014. Sanksi pidana bagi pelaku tindak eksploitasi ekonomi terhadap anak pada masa Pandemi Covid-19 tidak diatur secara khusus dalam Undang-undang. Namun terkait sanksi tindak pidana eksploitasi ekonomi terhadap anak secara umum diatur dalam Undang-undang Perlindungan anak. Apa bila pelakunya orangtua/wali atau pengasuh anak melakukan segala bentuk perlakuan eksploitasi, maka pelaku dikenakan pemberatan hukum.

\section{Saran}

Berdasarkan pembahasan dan simpulan di atas, maka saran dalam penelitian ini adalah diharapkan kepada pemerintah, agar disusun aturan yang lebih jelas dan spesifik mengenai eksploitasi anak khususnya yang dipaksa untuk berdagang asongan. Selain itu diperlukan hukuman pidana yang lebih berat agar orang tua atau wali tidak dengan mudahnya melakukan eksploitasi terhadap anak. Terhadap masyarakat, agar memberikan pengawasan dan perhatian terhadap pedagang asongan yang masih di bawah umur atau anak-anak. Untuk peneliti selanjutnya, untuk bisa menggunakan metode penelitian secara empiris agar dapst mengetahui secara nyata di lapangan berkaitan penerapan dari peraturan Perundang-undangan tentang eksploitasi anak.

\section{DAFTAR PUSTAKA}

Anggraini, M. (2020). Fenomena Pekerja Anak (Kasus Pedagang Asongan Anak di Kawasan Ekonomi Khusus Mandalika, Lombok Tengah). Jurnal Respirokal,2(1).

Asikin, Z., \& Amiruddin. (2012). Pengantar Metode Penelitian Hukum. Raja Grafindo Persada: Jakarta.

Atmasasmita, R. (1997). Peradilan Anak di Indonesia. Mandar Maju: Bandung.

Edy, D. W., Dewi, A. A. S. L., \& Widyantara, I. M. M. (2020). Perlindungan Hukum Terhadap Anak 
Di Bawah Umur Sebagai Pengemis, Jurnal Interpretasi Hukum, Vol. 1, No. 2, hal. 105. 1(2), 104-109.

Fitriani, R. (2016). Peranan Penyelenggara Perlindungan Anak Dalam Melindungi Dan Memenuhi Hak-Hak Anak. Jurnal Hukum Samudra Keadilan, 11(2), 250-358.

Hutahaean, B. (2013). Penerapan Sanksi Pidana Anak. Jurnal Yudisial, 6(1).

Manggala, I. G. F., Dewi, A. A. S. L., \& Suryani, L. P. (2021). Tinjauan Yuridis Tindak Pidana Kebiri dalam Perspektif Hak Asasi Manusia. Jurnal Konstruksi Hukum, 2(1), 46-51.

Marlienna, E. (2017). Analisis Yuridis Tindak Pidana Eksploitasi Anak yang Dilakukan oleh Orang Tua. University Research.

Nashriana. (2011). Perlindungan Hukum Bagi Anak di Indonesia. PT Raja Grafindo Persada.

Piri, M. T. (2013). Perlindungan Hukum Terhadap Tindakan Eksploitasi Anak (Kajian UndangUndang Nomor 23 Tahun 2002). Lex Administratum, 1(2), 28.

Pramandari, P. Y., \& Parwita, G. B. S. (2013). Aspek Sosial Ekonomi dan Budaya dalam Tingkat Kesejahteraan Masyarakat Tenganan Pegringsingan. Equilibrium, 11(1), 34-41.

Raharjo. (2002). Polri Sipil dan Perubahan Sosial di Indonesia. Kompas: Jakarta.

Subhan. (2018). Eksploitasi Anak Jalanan di Pantai Amahami Kota Bima. Jurnal Komunikasi Dan Kebudayaan, 5(1), 88-94. 